Boletín de la Sociedad Geológica Mexicana

VOLUMEN 61, NÚM. 2, 2009, P. 215-224

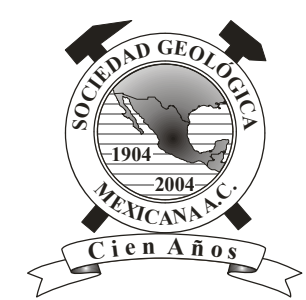

\title{
On the occurrence of Gillicus arcuatus (Cope, 1875) (Pisces, Ichthyodectiformes $\uparrow$ ) in Mexico
}

\author{
Jesús Alvarado-Ortega ${ }^{1, *}$, Héctor Porras- Múzquiz ${ }^{2}$ \\ ${ }^{1}$ Departamento de Paleontología, Instituto de Geología, Universidad Nacional Autónoma de México. Ciudad Universitaria, Coyoacán, \\ D.F., 04510, México \\ ${ }^{2}$ Museo Histórico de Múzquiz, Ayuntamiento de Múzquiz. Hidalgo Norte 205, Zona Centro, Múzquiz, Coahuila, C.P. 26340, México \\ *jalvaradoortega@yahoo.com.mx
}

\begin{abstract}
This work provides the description of the first specimen of the species Gillicus arcuatus (Cope, 1875) collected in Mexico. This ichthyodectiform fossil was collected in a marl flagstone quarry on Los Pilotes Ranch, Muzquiz County, Coahuila. The rocks of the quarry are of Turonian age, and constitute part of the Eagle Ford Formation. This Gillicus arcuatus specimen fits within the known temporal distribution of Gillicus, but extends the geographical distribution of this species to include Northern Mexico, where once the North American Western Interior Sea and the Western Tethys Sea converged. Los Pilotes Ranch is the southernmost fossil locality so far known where Gillicus has been found.
\end{abstract}

Keywords: Gillicus, Ichthyodectiformes, Turonian, Eagle Ford Formation, Coahuila.

\section{Resumen}

Se describe el primer ejemplar de la especie Gillicus arcuatus (Cope, 1875) colectado en México. Este fósil Ichthyodectiforme fue recolectado en las cantera de lajas margosas explotada en el Rancho Los Pilotes, Múzquiz, Coahuila, los cuales son de edad Turoniana y constituyen parte de la Formación Eagle Ford. Este ejemplar de Gillicus coincide con la distribución temporal conocida del género y extiende la distribución geográfica del mismo hasta el norte de México, en donde alguna vez se encontraban las aguas del Mar Interior de Norteamérica y del oeste del Mar de Tetis. Rancho Los Pilotes es la localidad más sureña hasta ahora conocida en donde se han colectado restos de este género.

Palabras clave: Gillicus, Ichthyodectiformes, Turoniano, Formación Eagle Ford, Coahuila 


\section{Introduction}

The Ichthyodectiformes are a primitive extinct group of basal teleosts established by Bardack and Sprinkle (1969). They appeared in the Middle Jurassic, became a diverse and successful group during almost all of the Cretaceous. Their fossils have been collected in marine deposits of North America, Europe, Lebanon, Australia, South America, Asia and Africa. Today, the order Ichthyodectiformes is subdivided in three suborders (Alvarado-Ortega, 2004; Taverne and Chanet, 2000). Occithrissopoidei includes Occithrissops Schaeffer and Patterson, 1984. Allothrissopoidei involves Allothrissops Nybelin, 1964, and Antractithrissops Arratia et al., 2004. The suborder Ichthyodectoidei includes at least eighteen genera: Saurocephalus Harlan, 1824; Saurodon Hays, 1830; Thrissops Agassiz, 1833; Cladocyclus Agassiz, 1841; Chiromystus, Cope, 1885; Proportheus Jaekel, 1909; Chirocentrites Heckel, 1849; Ichthyodectes Cope, 1870, Xiphactinus Leidy, 1870; Gillicus Hay, 1898; Prymnetes Cope, 1871a, Hay, 1898; Eubiodectes Hay, 1903, Cooyoo Lees and Bartholomai, 1987; Prosaurodon Stewart, 1999; Faugichthys Taverne and Chanet, 2000; Vallecillichthys Blanco and Cavin, 2003; Unamichthys, Alvarado-Ortega, 2004; and Heckelichthys Taverne, 2008.

When Bardack (1965) reviewed the chirocentrid fishes, a clupeomorph group that once included a large part of the genera located today within the order Ichthyodectiformes, he wrote in relation to the Mexican ichthyodectiforms known then: - it is too fragmentary for a positive assignment. Nevertheless, the study of fossils from an increasing number of fish localities recently discovered shows that the ichthyodectiforms are common elements in the Cretaceous assemblages of Mexico. To date, Mexican fossil fish specimens complete enough for reliable taxonomic assignation within this order are: 1) A Jurassic Thrissopslike specimen from Mazapil, Zacatecas (Villaseñor et al., 2006). 2) The Albian ichthyodectiforms from the Tlayúa quarry, Puebla, which include Unamichthys espinosai Alvarado-Ortega, 2004, and at least two other undescribed forms (Alvarado-Ortega, 2005). 3) The holotype and single specimen as far known of Prymnetes longiventer Cope, 1871a, from an unknown and perhaps Early Cretaceous locality near Tuxtla Gutiérrez, Chiapas [recently, some probable Prymnetes specimens were collected in El Chango quarry, near Tuxtla Gutiérrez, Chiapas (Ovalles-Damián et al., 2006). Although the age of El Chango quarry was considered as Albian by Vega et al. (2007), if its fossil fish assemblage is regarded it is probably Cenomanian (Alvarado-Ortega, pers. obs., 2008)]. 4) Vallecillichthys multivertebratum Blanco and Cavin, 2003, from the Turonian deposits at Vallecillo quarry, Nuevo León (see Blanco-Piñón and Alvarado-Ortega, 2007). 5) A specimen assigned to Saurodon from the Turonian marls of La Mula quarry, Múzquiz, Coahuila (Alvarado-Ortega et al., 2006a). 6) A few undescribed specimens that resemble Unamichthys from the Albian-Cenomanian outcrops of the Muhi quarry, Hidalgo State (Alvarado-Ortega, 2005). In addition, Alvarado-Ortega et al. (2006b) reported some Icthyodectoidei isolated remains from the Late Cretaceous sediments of the Mexcala Formation, Guerrero. Fish remains from Xilitla, San Luis Potosí, previously described by Maldonado-Koerdell (1956) as Xiphactinus and Ichthyodectes as well as one from Tlaxiaco, Oaxaca, reported by Felix (1891) as Thrissops, do not show enough characters to support such taxonomic identifications.

Hay (1898) named Gillicus, a fossil fish genus in order to include Portheus arcuatus Cope, 1875, and Ichthyodectes polymicrodus Crook, 1892. The specimens used to describe both species are from the Smoky Hill Chalk (Early Coniacian to Early Campanian) of the Niobrara Formation, Kansas (for age see Carpenter, 2003). Firstly, Cope (1875) described Portheus arcuatus based upon imperfect remains that later he referred to Ichthyodectes, thus naming the species $I$. arcuatus Cope, 1877. Crook (1892) described Ichthyodectes polymicrodus; right after, Cope (1892) recognized Crook's species as Ichthyodectes arcuatus. In Europe, Woodward (1901) named Ichthyodectes serridens based on a single specimen from the British Gault Clay (Albian), Folkestone, Kent, England; which Hay (1903) later placed within the genus Gillicus as G. serridens.

Bardack (1965, 1968), listed the synonyms of Gillicus arcuatus and the localities where its remains had been collected in the USA and Canada, including: Carlile Shale (Turonian-Santonian), Minnesota and South Dakota; Austin Chalk (Early Coniacian - Late Santonian),Texas; Pierre Shale (Early Coniacian to Early Campanian), Wyoming; and the Boyne Member of the Vermilion River Formation [McNeil and Caldwell (1981) recognized this member as the Niobrara Formation; nevertheless Christopher et al. (2006) integrated this member as the upper part of the Carlile Formation], Manitoba. Applegate (1970) reported the occurrence of Gillicus from Early Campanian Selma Formation sediments in Alabama (for age see Smith and Mancini, 1983). According to Stewart and Carpenter (cited in Carpenter, 2003), Gillicus is also present in Late Albian-Early Turonian sediments of the Dakota Formation, Colorado; and recently Tanimoto and Kinkyo (2001) found remains of this genus in the Lower Maastrichtian outcrops of Izumi group, Japan.

The aim of the present paper is to provide a description of the first Mexican fossil remain belonging to the species Gillicus arcuatus (Cope, 1875). Local workers discovered this specimen in 2006, during the quarrying of the Late Cretaceous (Turonian) marls that crop out into Los Pilotes Ranch, $130 \mathrm{Km}$ northwestof Múzquiz, Coahuila (Figure 1).

\section{Location and Geology}

The high quality of the vertebrate and invertebrate fossils recently collected in an increasing number of localities near Múzquiz, Coahuila, including Los Pilotes Ranch, has 


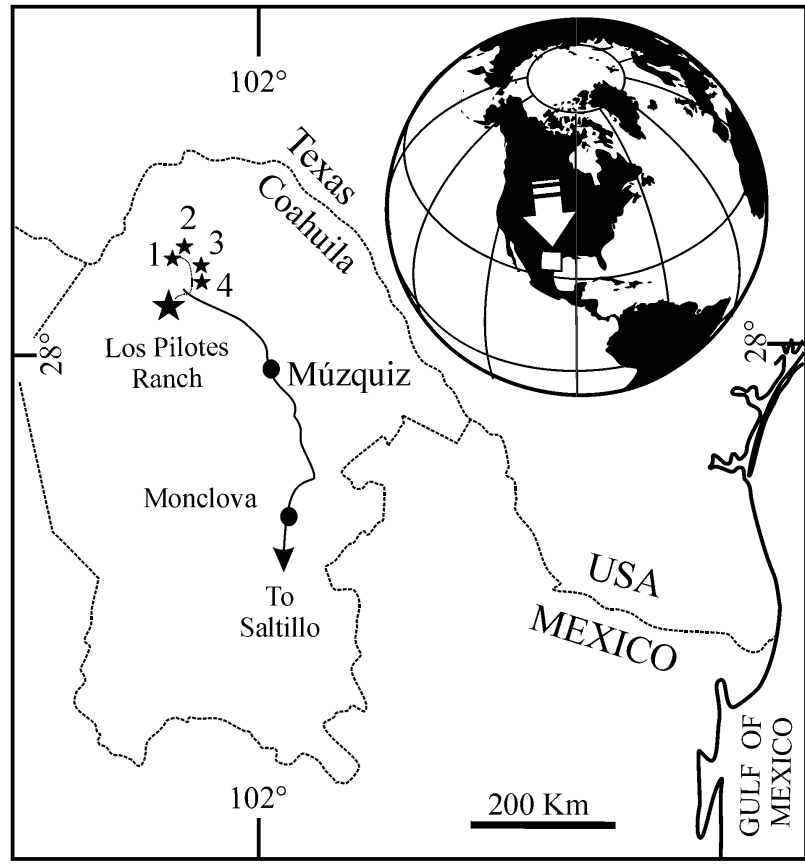

Figure 1. Map showing location of Los Pilotes Ranch and other fossil quarries near Múzquiz, Coahuila Nuevo León, México. 1, La Mula; 2, Venustiano Carranza; 3, Los Temporales; 4, El Rosario.

attracted the attention of paleontologists (Stinnesbeck et al., 2005; Alvarado-Ortega et al., 2006a). According to Vega et al. (2007), the marine fossil bearing strata exposed within Los Pilotes Ranch are equivalent in lithology and age (Turonian) to those described for La Mula quarry and the lower part of El Rosario quarry (see Nyborg et al., 2005; Stinnesbeck et al., 2005; Alvarado-Ortega et al., 2006a), also near Múzquiz.

Unfortunately the first fossils from Los Pilotes Ranch, including the Gillicus specimen herein described, do not have proper stratigraphic control because local workers have been the fossil collectors in Los Pilotes Ranch. Nevertheless, at present the fossil assemblage from this locality includes abundant teleostean fish remains belonging to Enchodus sp., Laminospondylus sp., a small Omosama-like fish, some complete unidentified clupeomorph fishes, and abundant isolated scales, as well as some remains of plesiosaurs, crustaceans, ammonites, inoceramids, and planktonic foraminifera. Additional fieldwork is required to recognize the stratigraphic position of the fossiliferous strata seen at Los Pilotes Ranch, and how it fits into the Late Cretaceous sequence of Northeastern Mexico.

Blanco-Piñón and Alvarado-Ortega (2005), as well as Stinnesbeck et al. (2005), noted that the vertebrates from the localities near Múzquiz (including Los Pilotes Ranch) are phosphatized and that in many cases they preserve soft tissues. According to these authors, this kind of fossil preservation suggests that the deposition of these specimens occurred on an open marine shelf with an oxygen-depleted bottom.

\section{Material and Methods}

\subsection{Abbreviations}

The abbreviations follow Patterson and Rosen (1977) and Alvarado-Ortega (2004) (see Figures 2-4).

Institutional abbreviations: AMNH, American Museum of Natural History, New York, USA; DNPM, Departamento Nacional de Produção Mineral, Brazil; IGM, Colección Nacional de Paleontología, Instituto de Geología, Universidad Nacional Autónoma de México; MUZ, Museo Histórico de Múzquiz, Coahuila, Mexico; UERJ-PMB, Universidade do Estado do Rio de Janeiro; USNM, United States National Museum, Smithsonian Institute, USA.

\subsection{Comparative material}

The following specimens were reviewed for comparative purposes;

Cladocyclus gardneri Agassiz, 1841: AMNH 1841, AMNH 11877, UERJ-PMB 510, UERJ-PMB 520; Early Cretaceous (Aptian-Albian), Romualdo Member, Santana Formation, Ceará, Brazil.

Gillicus arcuatus (Cope, 1875): AMNH 8571; Late Cretaceous, Niobrara Formation, Kansas, USA.

Ichthyodectes ctenodon Cope, 1870: AMNH 2005, AMNH 2005; Late Cretaceous, Niobrara Formation, Kansas, USA.

Prymnetes longiventer Cope, 1871a, USNM 4090 (silicone peel deposited in IGM), Chiapas, Mexico, from unknown locality and age.

Saurocephalus Harlan, 1824: DNPN 1269-P (Saurocephalus sp.), fragment of jaw, Late Cretaceous (Maastrichtian), Gramame Formation, Pernambuco, Brazil.

Saurodon Hays, 1830: IGM 6762 (Saurodon sp.), Late Cretaceous (Turonian), Eagle Ford Formation, La Mula Quarry, Coahuila, Mexico. AMNH 9907 (S. leanus), Late Cretaceous (Campanian), Niobrara Chalk, Montana, USA.

Unamichthys espinosai Alvarado-Ortega, 2004: IGM 8373 and IGM 8374, Early Cretaceous (Albian), Tlayúa Quarry, Middle Member of Tlayúa Formation, Puebla, Mexico.

\section{Systematic Paleontology}

Subdivision Teleostei Müller, 1845

Order Ichthyodectiformes Bardack and Sprinkle, 1969

Suborder Ichthyodectoidei Romer, 1966

Family Ichthyodectidae sensu Patterson and Rosen, 1977 (in part)

Subfamily Gillicinae Taverne, 2008 Genus Gillicus Hay, 1898 


\section{Gillicus arcuatus (Cope, 1875)}

\subsection{Referred specimens}

MUZ 47a and MUZ 47b (part and counterpart), a partial head showing both jaws and parts of the opercular series and ethmoid bones (Figures 2, 3).

\subsection{Preparation}

MUZ 47b was simply hardened because it only preserves the impression of the left side of the specimen as well as the internal view of some broken bones. MUZ 47a, which preserves both sides of the head, was prepared using pin vises under a stereoscopic microscope to remove fragments of loose clay matrix, and baths of $5 \%$ acetic acid to dissolve its limestone fraction, in order to disclosure the external surface of the right side of the head. The total preparation of MUZ 47b was not possible because the strong compression of the bones, as well as their permineralization by calcite, make them extremely fragile. At the end of the preparation, MUZ $47 \mathrm{a}$ and $\mathrm{b}$ were hardened with Glyptol.

\subsection{Locality}

The Turonian limestone marl strata at Los Pilotes Ranch, $180 \mathrm{Km}$ northwest of Múzquiz town, Coahuila, northeastern Mexico. According to Vega et al. (2007), these strata belong to the Eagle Ford Formation (Figure 1).

\subsection{Description}

\subsubsection{General features}

The specimen shows both sides of the head including part of the ethmoid area, upper and lower jaws, and fragments of the opercular series. The length of the head (from the tip of the ethmoid area to the posterior border of the opercle) is $17.5 \mathrm{~cm}$. Following the proportions of Gillicus published by Bardack (1965), who found that the head is contained 6.5 times in the standard length (SL), the SL of MUZ 47 could reach $114 \mathrm{~cm}$.

\subsubsection{Ethmoid area}

Although the ethmoid area is not entirely preserved, it shows the pattern found in other Cretaceous Ichthyodectiformes (Figure 2). Only the anterior tip of rostrodermethmoid is preserved; it is covering the anterodorsal border of the ethmoid area. The nasal capsule is not preserved except for part of its floor that shows both well ossified ethmopalatines, which also are preserved just partially (Figures 2 and 3). In MUZ 47b the ventral border of the ethmopalatine is projected over the anterior part of the maxilla and must reach the palatine head; here this bone has two concave articular surfaces, the anterior of these surfaces articulates the anterior dorsal process of the maxilla, and the posterior one must reach the rectangular and massive palatine head (not preserved) (Figure 3). The ventral section of the ethmopalatine, between its two concave articular surfaces, projects between both maxillary dorsal processes. Below the ethmopalatines there is an unpaired bone, very badly preserved, that could be the remains of a vomer or parasphenoid (Figure 3).

\subsubsection{Hyopalatine series}

Few elements of the hyopalatine series are preserved for an accurate description (Figure 2). An impression of the ventral section of hyomandibula is preserved above the quadrate. The impression of a large clove shaped symplectic is preserved on the preopercle in MUZ 47a. The quadrate is triangular in shape with a dorsal border slightly concave and a stout rounded articular head directed antero-ventrally. The anterior end of the palatine is massive and forms an expanded head (disclike malleolus sensu Patterson and Rosen, 1977) that articulates with the ethmopalatine (dorsally) and posterior maxillary dorsal process.

\subsubsection{Upper jaw}

The maxilla is saber-shaped; its oral profile is sinuous and it is straight dorsally (Figure 2). The depth along the maxilla is irregular due the sinuousness of its ventral profile and the gentle roundness of its posterior tip; nevertheless its middle and anterior sections are about $16 \mathrm{~mm}$ in depth and contained 4.6 times in the maxilla length $(75 \mathrm{~mm})$. The lateral face of this bone, mainly on the anterior half, is covered with tiny pores. The supramaxilla bears two stout, rectangular dorsal processes on its anterior third; the posterior articulates with the ventral border of the palatine head, whereas the anterior one articulates with the ethmoid bones. Although it is not clear what bones of the ethmoid area contact the facet for this anterior maxillary process, involvement of the ethmopalatine is probable (Figure 3). Regarding the space between preserved teeth and the size of the alveolar border of the maxilla, is possible to suggest that that this bone probably had 55 to 65 small, conical and hollow teeth located in deep sockets and forming a single row along its alveolar border. These teeth are about regular in shape and size (Figure 3), the mean of their crown height is around $1.5 \mathrm{~mm}$; nevertheless, those located on the concave section of the maxilla are slightly longer $(2 \mathrm{~mm})$. A lot of these teeth are regularly and so closely spaced that they almost contact each other (therefore the empty free spaces could be considered as empty alveoli where the dental replacement was occurring). The maxilla anterior tip shows a shallow notch in its lateral surface where the premaxilla attaches (Figure 2).

The premaxilla is rhomboidal, about twice deeper than long (Figure 2). This bone has a single articulation, in which the posterior part of its lateral internal surface attaches to the anterior and shallow facet of the maxilla. In MUZ 47, the premaxilla seems to overlap the ethmoid area, but it is not clear if this bone articulates with another bone. In MUZ 47 the premaxilla teeth resemble those described in the maxilla; 

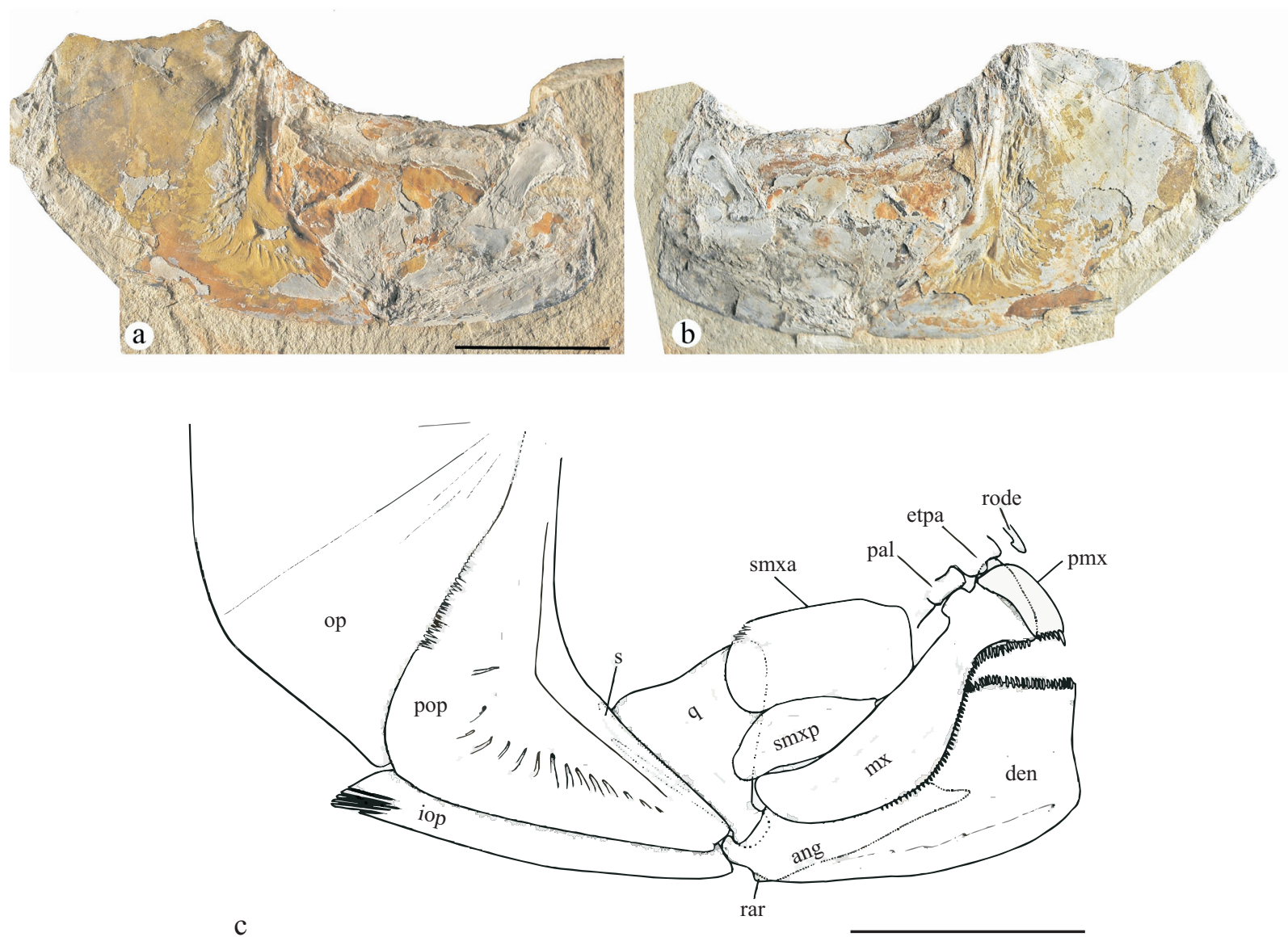

Figure 2. MUZ 47, Gillicus arcuatus, from Los Pilotes Ranch, Múzquiz County, Coahuila, Mexico. a, MUZ 47b (part), impression of the right side of the head. b, MUZ 47a (counterpart), right side of the head. c, Reconstruction of the specimen based on MUZ 47 a and b. Abbreviations: ang, angular; etpa, ethmopalatine; iop, interopercle; den, dentary; mx, maxilla; op, opercle; pal, palatine; pmx, premaxilla; pop, preopercle; rar, retroarticular; rode, rostrodermethmoid; s, symplectic; smxa, supramaxilla anterior, smxp, supramaxilla posterior; q, quadrate. Scale bars equal $5 \mathrm{~cm}$.

these are similar in shape and form a single row, but they are larger. This specimen preserves the impression of two fangs with $4 \mathrm{~mm}$ crown, followed by at least 4 teeth with crowns decreasing in length from 3 to $2 \mathrm{~mm}$ (Figure 2).

There are two supramaxillae covering the large part of the anterior surface of the cheek. The anterior supramaxilla is rectangular, the largest, and seems to be about twice the size of the ovoid posterior supramaxilla. Based on the impression of external bones found in MUZ 47b (Figure 2 ), it is considered herein that the posterior border of the anterior supramaxilla is finely denticulated or fringed, a condition that probably was also present in the posterior supramaxilla (Figure 2). The supramaxillae are placed above of the posterior half of the maxilla and its surfaces are ornamented with fine parallel grooves. These observations are in part estimated as neither the whole profiles nor surfaces of these bones are preserved.

\subsubsection{Lower jaw}

The lower jaw is rectangular (Figure 2, 3). The anterior border of the dentary symphysis is straight and respecting to its slightly convex ventral profile, it is projected upward forming an angle near to $90^{\circ}$. The retroarticular process is well developed, occupies the posterior fifth of the jaw, and externally it is made up by the angular. The length of the lower jaw in MUZ 47 is $75 \mathrm{~mm}$ along its ventral margin; its depth is $25 \mathrm{~mm}$ at the anterior edge of the symphysis. The symphysis is contained 3.0 times in the length of the dentary. At the base of the retroarticular process the jaw shows a robust, but small ventral protrusion that herein is interpreted as remains of the retroarticular bone. Although in MUZ 47, the dentary bone forms the large part of the lower jaw, many of its details are obscured or badly preserved. The coronoid process and a large part of the dentary alveolar border are covered. The anterior part of the alveolar border shows a gently sinuous profile in which a row of regular, conical, and hollow teeth about $2 \mathrm{~mm}$ in length are preserved. The lateral external surface shows some spaced pits for the mandibular sensory canal spaced along a ridge on its ventral margin.

\subsubsection{Opercular series}

The opercular bones are not well preserved; nevertheless 

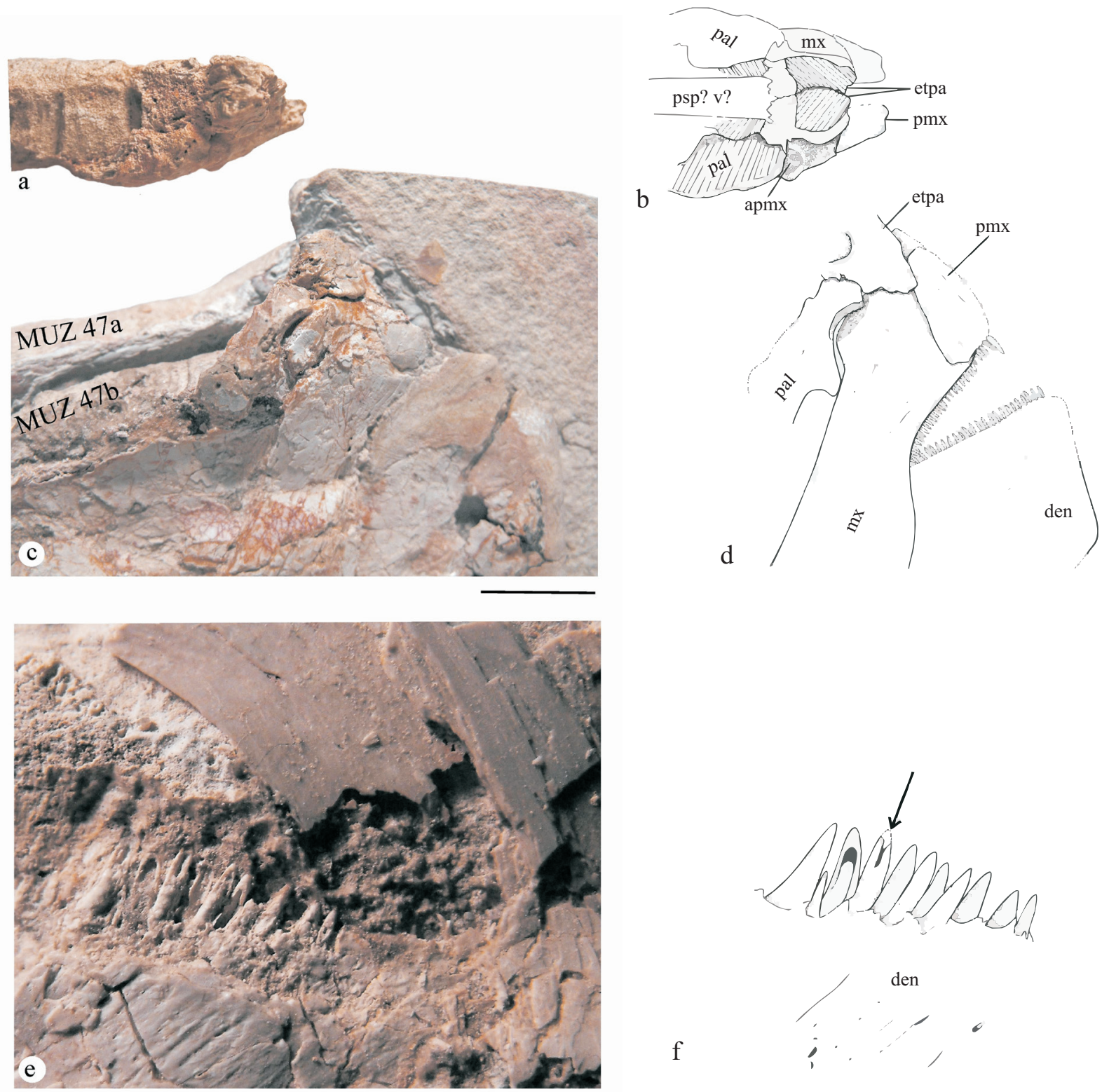

Figure 3. Details of MUZ 47, Gillicus arcuatus from Los Pilotes Ranch, Múzquiz, Coahuila. a and b, MUZ 47b, dorsal view and reconstruction of the ethmoid area. c, MUZ 47b after preparation (overlapped on MUZ 47a) and showing a close-up of left side of the ethmoid area. d, reconstruction of ethmoid area and jaws based on c. e and f, hollow dentary teeth (see arrow) preserved in MUZ 47b (right side of the head) and reconstruction. Abbreviations: apmx, anterior articular process of the maxilla; etpa, ethmopalatine; den, dentary; mx, maxilla; pal, palatine; pmx, premaxilla; psp, parasphenoid; v, vomer. Scale bars equal $2 \mathrm{~cm}$.

some of them show discernable characters (Figure 2). Althougth the opercle lacks its dorsal border, in lateral view this bone is kidney-shaped, almost flat, and shows radiating ridges displaced from the hyomandibular facet (not preserved in MUZ 47). The preopercle shows the typical L-shape, in which the dorsal limb is the larger and the ventral border is projected forward reaching the posterior border of the lower jaw. The preopercle has a gently curved anterior margin and slightly concave ventral profile. A well-expanded wing of thin bone forms the posteroventral corner of this bone. The section preserved of the preopercle dorsal limb shows a finely denticulated or fringed margin. The preopercular sensory canal has 12 pits on the ventral and three on the dorsal branch. The interopercle is a long and shallow flat bone, located below, and overlapped by the preopercle. The interopercle shows a deeply denticulated or fringed posterior margin.

\subsubsection{Scales}

MUZ 47 has a single scale exposed on its lateral surface; it is located beyond the opercle. This scale is ovoid, slightly deeper than long, and shows a number of central pits. No 
other external ornaments (circuli or radii) are visible on this scale.

\section{Discussion}

Although MUZ 47 is largely incomplete, it is recognizable as a member of the order Ichthyodectiformes because a pair of well ossified ethmopalatine bones occupies the nasal capsule floor, articulating with the dorsal head of the palatine (Figure $3)$. According to Patterson and Rosen (1977), the occurrence of the ethmopalatines is a synapomorphic character of the order Ichthyodectiformes. These authors also noted that the species placed in the suborder Ichthyodectoidei share the presence of other synapomorphic characters; the large head of the palatine has disclike malleolus shape, and the ethmopalatine is completely ossified (with membranous outgrowths forming a complex suture that strongly attaches this bone to the rostrodermethmoid anteriorly and lateral ethmoid posteriorly). MUZ 47 shows both these diagnostic characters, supporting its inclusion within the suborder Ichthyodectoidei.

Patterson and Rosen (1977) included all Cretaceous ichthyodectiform genera then known plus the Jurassic European Thrissops species in the suborder Ichthyodectoidei. Although Patterson and Rosen (1977) recognized only two Ichthyodectoidei families (Saurodontidae and Ichthodectidae), since then new ideas on the systematics of this suborder have been put forward involving the higherlevel systematics of the group and its included families (Taverne, 1975, Maisey, 1991; Stewart, 1999; Taverne and Chanet, 2000; Alvarado-Ortega, 1998, 2004, 2005, and Taverne 2008).

\subsection{Saurodontidae}

This family was originally erected by Cope (1871b) (also see Bardak and Sprinkle, 1969) to include Saurodon and Saurocephalus, and today it also includes Prosaurodon (see Stewart 1999). The saurodontids are highly specialized strongly prognathous fishes that evolved an unusually long lower jaw and a triangular, edentulous predentary that together are projected forward beyond the premaxilla. MUZ 47 does not show any of these specialized saurodontid characters on its lower jaw, precluding its inclusion within this family. This family corresponds to the subfamily Saurodontinae suggested by Taverne and Chanet (2000) and Taverne (2008).

\subsection{Ichthyodectidae}

This family was originally erected by Crook (1892) to include Gillicus, Xiphactinus and Ichthyodectes; this group was considered as the subfamily Ichthyodectinae by Taverne and Chanet (2000). Patterson and Rosen (1977) considered the family Ichthyodectidae to include Thrissops and all the Cretaceous non-saurodontid ichthyodectiforms. Maisey (1991) reestablished the original composition of the family Ichthyodectidae. Later, Stewart (1999) pointed out the paraphyletic condition of this family. Finally, Blanco-Piñón and Alvarado-Ortega (2007) suggested the rearrangement of Crook's (1892) family, arguing the inclusion of Vallecillichthys and the possible exclusion of Gillicus. The family Ichthyodectidae sensu Taverne and Chanet (2000) and Taverne (2008) corresponds to the suborder Ichthyodectoidei suggested by Patterson and Rosen (1977). However, the family Ichthyodectidae sensu Patterson and Rosen (1977) represents an unnatural group (see Alvarado-Ortega 2005). In this paper Ichthyodectidae is used in part in the Systematic Palaeontology section just to retain the subfamily Gillicinae, recently named by Taverne (2008) to suggest a new hypothesis of Gillicus relationships.

According to Blanco-Piñón and Alvarado-Ortega (2007), the monophyly of the group comprised of Ichthyodectes, Xiphactinus and Vallecillicthys is supported by the occurrence of a broad parasphenoid angle (the ventral surface formed between the otic and ocular section of the parasphenoid ranges between $149^{\circ}-160^{\circ}$ ), the hyomandibular facet and ocular section of the parasphenoid projected in parallel to each other, and enlarged premaxilla fangs. Nevertheless, Taverne (2008) later suggested two additional characters, an increase in the number of vertebrae and a short anal fin (with only 11-13 rays). Although none of these characters is preserved in MUZ 47 except the presence of anterior fangs in the premaxilla, the exclusion of this fish from this group is strongly justified because the occurrence of a very deep lower jaw. The lower jaw in Ichthyodectes, Xiphactinus, and Vallecillichthys is rectangular and comparable to those seen in Erly Cretaceous Ichthyodectiformes (Unamichthys, Cladocyclus, Chiromystus, and Eubiodectes); in contrast, in MUZ 47 and other Gillicus specimens the lower jaw is very deep (see below). In other wise, the fangs in the premaxilla is a homoplasic character [these fangs are noted in Jurassic and other Cretaceous ichthyodectoids (see Maisey, 1991, among others) and their sizes are not easily comparable among these genera]. In MUZ 47 and other Gillicus specimens these teeth are always millimetric.

\subsection{Cladocyclidae}

Maisey (1991) named this family to include Cladocyclus, Chiromystus and Chirocentrites, indicating that only in these fishes the posterior border of the supraoccipital crest overhangs the occiput. Alvarado-Ortega (1998, 2004, 2005) and Stewart (1999) demonstrated that this is an unnatural group because the condition could be a plesiomorphy among ichthyodectoids and it has been seen in Thrissops and Xiphactinus.

\subsection{Unamichthydae}

Alvarado-Ortega (2004) suggested placing Unamichthys 
in its own family. The singularity of this genus (and family) is supported by the occurrence of unfused parietal bones. Cavin (2008) based on an unpublished work [addresses as Cavin \& Forey (2008)], suggested that Unamichthys and both Gillicus species (G. serridens and G. arcuatus) form a monoplyletic group; nevertheless the differences between Gillicus and Unamichthy include the dissimilar proportions of their lower jaws among other characters (see below).

Regarding the published phylogenetic hypotheses on Ichthyodectiformes (Maisey, 1991; Alvarado-Ortega, 1998, 2004, 2005; Stewart, 1999; Taverne and Chanet, 2000; and Taverne 2008), it is possible to address a remarkable tendency in the evolution of the lower jaw among the ichthyodectoids (Figure 4). Thrissops is the basal and the single Jurassic ichthyodectoid so far known; other Jurassic Ichthyodectiforms (Allothrissops, Antarcticthrissops, and Occithrissops), and basal teleosts such as Leptolepis coryphaenoides (see Wenz, 1967), show the plesiomorphic condition that consists of a triangular lower jaw, in which the dentary has an alveolar border projected anteroventrally, from a shallow symphysis to a wide and deep posterior coronoid process, and where the anterior border or symphysis depth is contained about 8 times in the length of its ventral border. Among the Cretaceous ichthyodectiforms the lower jaw is rectangular, and the alveolar and ventral borders are projected almost in parallel to each other. This shape is found in all ichthyodectoid genera so far known, except Thrissops, and if its proportions are regarded it has at least three derived conditions (Figure 4). In Cladocyclus as probably Chiromystus [a valid genus that Taverne (2008) regards synonymous of Cladocyclus], Unamichthys, Eubiodectes, Xiphactinus, Ichthyodectes, Vallecillichthys, Cooyoo, Hakelichthys, and Prosaurodon, the rectangular lower jaw is moderately deep; here the alveolar border length is contained about 4-5 times in the length of the ventral border of dentary. In saurodontids the rectangular lower jaw seems to be shallow because this ratio is about 6 times, causing them to have prognathic lower jaws. Finally, Gillicus and Chirocentrites coronini, which constitute Taverne's (2008) subfamily Gillicinae, have extremely deep lower jaws, such that the ratio of depth to length ranges between 2-3 times. Taverne (2008) redescribed the species placed within Chirocentrites, leaving $C$. coronini as the single member of this genus and erecting the genus Heckelichthys to place $H$. vexillifer and $H$. microdon (previously known as Chirocentrites vexillifer

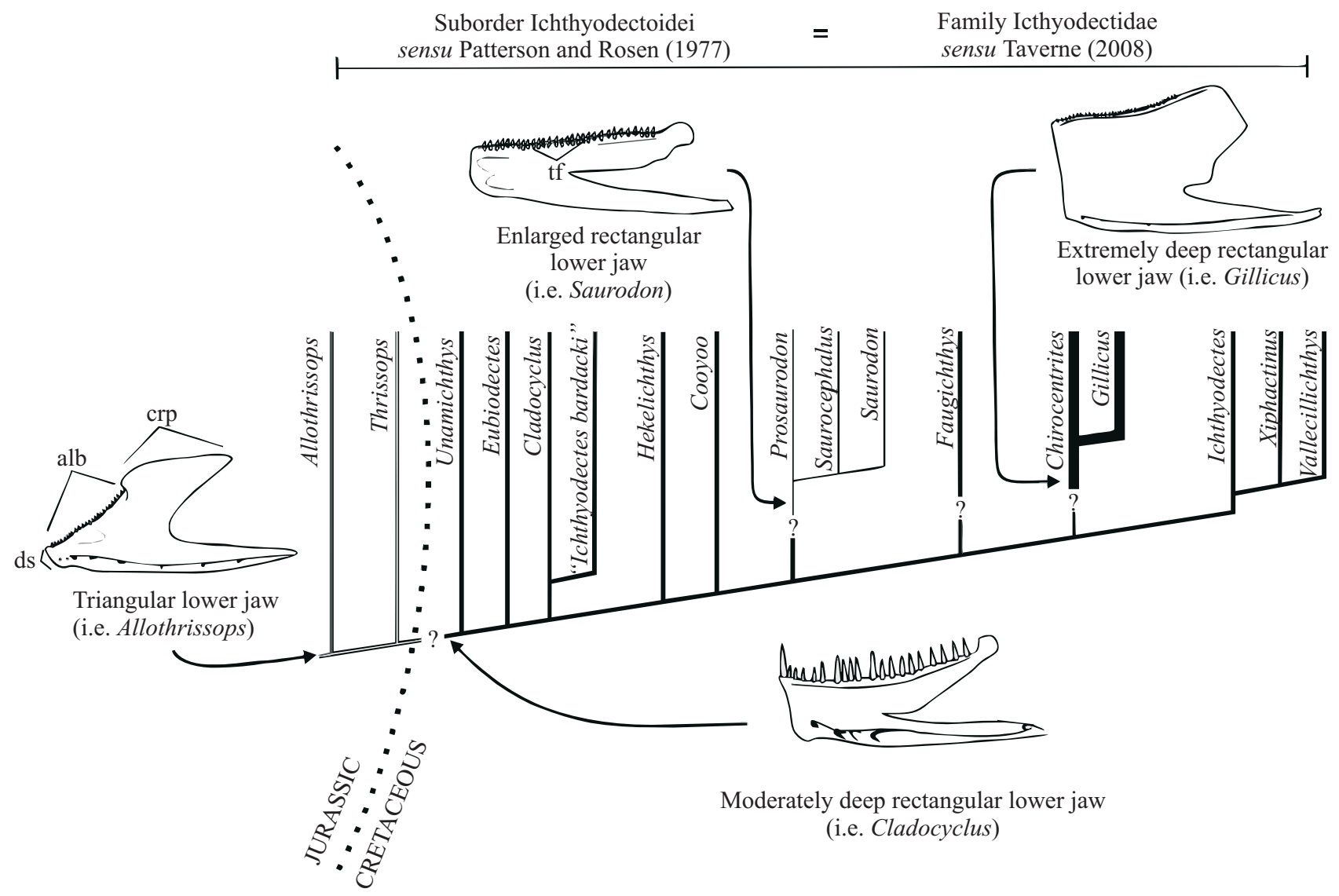

Figure 4. Dentary shapes found among Ichthyodectiformes drawn on Taverne's (2008) phylogenetic hypothesis (question marks added by the authors). All dentaries shown in external lateral view except Saurodon, shown in medial view. Abbreviations: alb, alveolar border; ds, dentary symphysis; crp, coronoid process; tf, tooth foramen. 
and C. microdon, respectively). According Taverne (2008), Chirocentrites differs from Gillicus because the former bears irregular and larger teeth, which in the anterior end of the premaxilla and dentary become fangs. In Gillicus, the teeth are minute and regular in shape. MUZ 47 is identified as Gillicus because the proportions of its symphysis match with those seen in Gillicinae and the teeth are like those described for Gillicus species (compare dentary bones in the Figures 2 and 4). Additionally, the maxilla ventral border is concave in Gillicus (Bardack, 1965) and gently convex in Chirocentrites corinini (Taverne 2008, fig. 2); here again, MUZ 47 most closely resembles Gillicus.

Although Bardack $(1965,1968)$ recognized that Gillicus arcuatus and G. serridens are valid species, he noted that they do not show morphological differences from each other. He considered that these species are "tentatively distinct" only because they have "different geographic and geological positions." Since Bardack's work, new fossils of Gillicus have been collected in localities within a wide geographical and temporal distribution (it is known from North America, Europe, and Eastern Asia, and ranged in age from Late Albian to Early Maastrichtian); nevertheless a detailed review and a comparative study still are required to confirm the validity of both Gillicus species. Regarding that $G$. serridens is just "tentatively distinct" from $G$. arcuatus and that they do not show significative differences as Bardack (1965) noted, herein MUZ 47 is identified as Gillicus arcuatus as it fits the description as well as temporal of the type species.

\section{Conclusions}

Specimen MUZ 47, collected in the Turonian limestone marl strata at Rancho Los Pilotes, near Múzquiz, Coahuila, shows enough characters for its confident identification as a specimen belonging to the species Gillicus arcuatus. This is the first record of this genus within Mexican territory. The occurrence of this specimen represents the southernmost record of this genus so far collected.

\section{Acknowledgments}

The authors are deeply grateful to A. M. Rocha Torrallardona and Luis Espinosa Arrubarrena for their technical support. Also we thanks to A. Murray and S. Cumbaa for their important contributions and English improvement. A. Altamira prepared all the photographs included in this article. M.J.P. Nuñez-Utrilla and G. Alvarez Reyes prepared the specimen herein studied. We thank A. Cristin-Ponciano, F. Riquelme, and M.J.P. Nuñez-Utrilla for their enthusiastic assistance and partnership during the 2006 and 2007 field trip seasons. UNAM provided the financial support through the project PAPIIT IN225008.

\section{References}

Agassiz, L., 1833-1844, Recherches sur les poissons fossiles: Neuchâtel et Soleure, 5 volumes.

Agassiz, J.L.R., 1841, On the fossil fishes found by Mr. Gardner in the Province of Ceará, in the North of Brazil: Edinburgh New Philosophical Journal, 30, 82-84

Alvarado-Ortega, J., 1998, Ichthyodectiformes mexicanos -un análisis de su diversidad-, in Carranza-Castañeda O., Córdoba-Méndez, D.A. (eds.), Avances en Investigación, Paleontología de Vertebrados: Universidad Autónoma del Estado de Hidalgo, Instituto de Investigaciones en Ciencias de la Tierra, publicación especial, 109-119.

Alvarado-Ortega, J., 2004, Description and relationships of a new ichthyodectiform fish from the Tlayúa Formation (Early Cretaceous: Albian), Puebla, Mexico: Journal of Vertebrate Paleontology, 24 (4), 802-813.

Alvarado-Ortega, J., 2005, Sistemática de los peces Ichthyodectiformes de la Cantera Tlayúa, Puebla, México: D.F., México, Universidad Nacional Autónoma de México, Instituto de Geología, Tesis de Doctorado.

Alvarado-Ortega, J., Blanco-Piñon, A., Porras-Múzquiz, H., 2006a, Primer registro de Saurodon (Teleostei: Ichthyodectiformes) en México: Revista Mexicana de Ciencias Geológicas, 23 (1), 107-112.

Alvarado-Ortega J., Garibay-Romero, L.M., Blanco-Piñón, A., GonzálezBarba, G., Vega-Vera, F. J., Centeno-García, E., 2006b, Los peces fósiles de la Formación Mexcala (Cretácico Superior) en el Estado de Guerrero, México: Revista Brasileira de Paleontología, 9 (3), 261-272.

Applegate, S.P., 1970, The vertebrate fauna of the Selma Formation of Alabama, Part VIII, The Fishes: Fieldiana Geology Memoirs, 3 (8), 383-433.

Arratia G., Scasso, R.A., Kiessling, W., 2004, Late Jurassic fishes from Longing Gap, Antarctic Peninsula: Journal of Vertebrate Paleontology, 24 (1), 41-51.

Bardack, D., 1965, Anatomy and evolution of chirocentrid fishes: The University of Kansas Paleontological Contributions, Vertebrata, $10,1-88$.

Bardack, D., 1968, Fossil vertebrates from the marine Cretaceous of Manitoba: Canadian Journal of Earth Sciences, 5, 145-153.

Bardack, D., Sprinkle, G., 1969, Morphology and relationships of saurocephalid fishes: Fieldiana Geology, 16(12), 297-340.

Blanco, A., Cavin, L., 2003, New Teleostei from the agua Nueva Formation (Turonian), Vallecillo (NE Mexico). Comptes Rendus Palevol, 2, 299-306.

Blanco-Piñón, A., Alvarado-Ortega, J., 2005, Fishes from la Mula Quarries, a new Late Cretaceous Locality from The vecinity of Múzquiz, Coahuila, NE México, in Poyato-Ariza, F. J. (ed.), Fourth Internacional Meeting on Mesozoic Fishes - Systematics, Homology, and Nomenclature, Extended Abstracts, Miraflores de la Sierra, Madrid: España, UAM ediciones, 37-41.

Blanco-Piñón, A., Alvarado-Ortega, J., 2007, Review of Vallecillichthys multivertebratum (Teleostei: Ichthyodectiformes), a Late Cretaceous (Early Turonian) Bulldog fish from Northeastern Mexico: Revista Mexicana de Ciencias Geológicas, 24(3), 450-466.

Carpenter, K., 2003,Vertebrate Biostratigraphy of the Smoky Hill Chalk (Niobrara Formation) and the Sharon Spring Member (Pierre Shale), in Harries, P.J. (ed.), High-Resolution Approaches on Stratigraphic Paleontology: Kluwer Academic Publishers, Topics in Geobiology, 21, 421-437.

Cavin, L., 2008, Palaeobiogeography of Cretaceous bony fishes (Actinistia, Dipnoi and Actinopterygii): Geological Society, London, Special Publications 2008, 295, 165-183.

Christopher, J.E., Yurkowski, M., Nicolas, M., Bamburak, J., 2006, The Upper Cretaceous (Turonian-Santonian) Carlile Formation of Eastern Southern Saskatchewan, and the Correlative Morden and Boyne Members of Southwestern Manitoba: Summary of Investigations 2006, Volume 1, Saskatchewan Geological Survey, Sask. Industry Resources, Miscellaneous Report 2006, 4.1, A-13. 
Cope, E.D., 1870, On the Saurodontidae: American Philosophical Society, Proceedings, 11, 529-538.

Cope. E. D., 1871a, On two extinct forms of Physostomi of the Neotropical region: Proceedings of the American Philosophical Society, 12, 52-55.

Cope, E.D., 1871b, On the fossil reptiles and fishes of the Cretaceous rocks of Kansas: United States Geological Survey of Wyoming and portions of the Contiguous Territories (F.V. Hayden), 4th Annual Report, 385-242.

Cope, E.D., 1875, The vertebrata of the Cretaceous formations of the west: Report. US Geological Survey Territories, 2, 1-303.

Cope, E.D., 1877, On some new or little known reptiles and fishes of the Cretaceous number 3 of Kansas: American Philosophical Society, Proceedings, 17, 176-181.

Cope, E.D., 1885, A contribution to the Vertebrate Paleontology of Brazil: Proceedings of the American Philosophical Society, 17, 176-181.

Cope, E.D., 1892, Crook on Saurodontidae from Kansas: American Naturalist, 26, 941-942.

Crook, A.R., 1892, Über einige fossile Knochenfische aus der mittleren Kreide von Kansas: Palaeontographica, 39, 107-124.

Felix, J., 1891, Versteinerungen aus der mexicanischen Jura und Kreide Formation: Palaeontographica, 37, 140-194.

Harlan, R., 1824, On a new fossil of genus of the order Enalio Sauri (of Conybeare): Journal of the Academy of Natural Sciences of Philadelphia, 3, 331-337.

Hay, O.P., 1898, Notes on species of Ichthyodectes, including the new species I. cruentus, and on the related and herein established genus Gillicus: American Journal of Science, 6, 225-232.

Hay, O.P., 1903, On a collection of upper Cretaceous fishes from Mount Lebanon, Syria, with descriptions of four new genera and nineteen new species: Bulletin of the American Museum of Natural History, $19,395-451$.

Hays, I., 1830, Description of a fragment of the head of a new fossil animal discovered in a marl pit near Moorestown: Transactions American Philosophical Society, 3, 471-477.

Heckel, J.J., 1849, Abhandlung über eine neue fossile Fischgattung, Chirocentrites, und die ersten Überrste eines Siluroiden aus der Vorwelt: Akademie der Wissenchaften, MathematischNaturwissencha, Klasse Denkschriften der Kaiserlichen, Sitzungsber, 2 (1), 16-19.

Jaekel, O., 1909, Beiträge zur Geologie von Kamerun. X. Fischreste aus der Mamfe Shiefern: Köriglische Preussische Geologische Landesantstalt, Abhandlung, new series, 6, 392-398.

Lees, T., Bartholomai, A., 1987, Study of a Lower Cretaceous actinopterygian (Class Pisces) Cooyoo australis from Queensland, Australia: Memoirs of the Queensland Museum, 25 (1), 177-192.

Leidy, J., 1870, Remarks on ichthyodorulites and on certain fossil mammalians: American Philosophical Society, Proceedings, 22, $12-13$.

Maisey, J.G., 1991, Santana Fossils: An illustrated Atlas: T.F.H. Publications Inc., New Jersey.

Maldonado-Koerdell, M., 1956, Peces fósiles de México III. Nota preliminar sobre peces del Turoniano superior de Xilitla, San Luis Potosí, México: Ciencia, México, 16, 31-36.

McNeil, D.H., Caldwell, W.G.E., 1981, Cretaceous rocks and their foraminifera in the Manitoba Escarpment: Geological Association of Canada, St. John's, Newfoundland, Geological Association of Canada, Special Paper, 21, 439.

Müller, J., 1845, Fernere Bemerkungen über der Bau der Ganoiden: Akademie der Wissenschaften zu Berlin, 1846, 67-87.

Nybelin, O., 1964, Versuch einer taxonomischen revision der jurassichen fischgattung Thrissops Agassiz: Meddeland Från Götemborgs, Museui Zoologiska Avdeling, 135, 1-44.

Nyborg, T., Alvarado-Ortega, J., Blanco, A., Vega, F.J., 2005, Taphonomy of fish preserved within ammonite chambers from the Upper Cretaceous Austin Group, Coahuila, México, in Geological Society of America, Abstracts with Programs, 37, 158.

Ovalles-Damián, E., Alvarado-Ortega, J., Blanco-Piñón, A., 2006, Los peces fósiles del Cretácico inferior de Ocozocuautla, Chiapas, in
Memorias del X Congreso Nacional de Paleontología: Sociedad Mexicana de Paleontología, México.

Patterson, C., Rosen, D.E., 1977, Review of ichthyodectiform and other Mesozoic teleost fishes and the theory and practice of classifying fossils: Bulletin of the American Museum of Natural History, 158, 81-172.

Romer. A.S., 1966, Vertebrate Paleontology. University of Chicago Press.

Schaeffer, B., Patterson, C., 1984, Jurassic fishes from the western United States, with comments on Jurassic fish distributions: American Museum Novitates, 2796, 1-86.

Smith, C.C., Mancini, E.A., 1983, Calcareous nannofossil and planktonic foraminiferal biostratigraphy, in Russell, E.E., Keady, D.M., Mancini, E.A., Smith, C.C. (Eds.), Upper Cretaceous Lithostratigraphy and Biostratigraphy in Northeastern Mississippi, Southwest Tennessee and Northwest Alabama, Shelf Chalks and Coastal Clastics: Society of Economic Paleontologists and Mineralogists, Spring Field Trip, April 1983, 16-28.

Stewart, J.D., 1999, A new genus of Saurodontidae (Teleostei: Ichthyodectiformes) from the Upper Cretaceous rocks of the Western Interior of North America, in Arratia, G., Schultze, H-P. (eds.), Mesozoic Fishes 2 -Systematics and Fossil Record-: München, Germany, Verlag Dr. Friedrich Pfeil, 335-360.

Stinnesbeck, W., Ifrim, C., Schmidt, H., Rindfleisch, A., Buchy M.C., Frey, E., González-González, A.H., Vega F.J., Cavin L., Keller, G., Smith, K.T., 2005, A new lithographic limestone deposit in the Upper Cretaceous Austin Group at El Rosario, county of Múzquiz, Coahuila, northeastern Mexico: Revista Mexicana de Ciencias Geológicas, 22 (3), 401-418.

Tanimoto, M., Kinkyo, T., 2001, Gillicus skeleton from the Upper Cretaceous Izumi Group (Lower Maastrichtian) of Yura-Cho, Sumoto City, Hyogo Prefecture, Southwest Japan the first find of a fossil of the family Ichthyodectidae in Japan: Chigakukenkyu, 50 (1), 41-43.

Taverne, L., 1975, Considérations sur la position systématique des genres fossils Leptolepis et Allothrissops au sein des Téléostéens primitives et sur 1'origine et le polyphylétisme des Poissins Téléostéens: Académie Royale de Belgique, 61 (5), 336-371.

Taverne, L., 2008, Considerations about the Late Cretaceous genus Chirocentrites and erection of the new genus Heckelichthys (Teleostei, Ichthyodectiformes) - A new visit inside the ichthyodectid phylogeny, in Steurbaut, E., Jagt, J.W.M., Jagt-Yazykova, E.A. (eds.), Annie V. Dhondt Memorial Volume: Bulletin de l'Institut royal des Sciences naturelles de Belgique, Sciences de la Terre, 78, 209-228.

Taverne, L., Chanet, B., 2000, Faugichthys loryi n. gen., n. sp. (Teleostei, Ichthyodectiformes) de l'Albien terminal (Crétacé inférieur marin) du vallon de la Fauge (Isère, France) et considérations sur la phylogénie des Ichthyodectidae: Geodiversitas, 22, 23-34.

Vega, F.J., Nyborg, T., Rojas-Briceño, A., Patarroyo, P., Luque, J., PorrasMúzquiz, H., Stinnesbeck, W., 2007, Turonian Crustacea from Mexico and Colombia Upper Cretaceous Crustacea from Mexico and Colombia, similar faunas and environments during Turonian times: Revista Mexicana de Ciencias Geológicas, 24 (3), 403-422.

Villaseñor, A.B., Silva-Martínez, L.E. Olóriz, F., Blanco, A., AlvaradoOrtega, J., 2006, Nuevo registro de peces Jurásicos en México, in Memorias del X Congreso Nacional de Paleontología: Sociedad Mexicana de Paleontología.

Wenz, S., 1967, Compléments à l'Étude des Poissons actinoptérygiens du Jurassique français: Cahiers de Paléontologie, Éditions du Centre National de la Recherche Scientifique, 276.

Woodward, A. S., 1901, Catalogue of fossil fishes in the British Museum (Natural History). British Museum (Nat. History), London, 4, (39), 544, 18 pl., 45 fig.

Manuscript received: February 27, 2009.

Corrected manuscript received: June 1, 2009.

Manuscript accepted: June 5, 2009. 